\title{
The Impact of Procedural Knowledge on the Formation of Declarative Knowledge: How Accomplishing Activities Designed for Developing Learning Skills Impacts Teachers' Knowledge of Learning Skills
}

\author{
Katrin Saks *(D), Helen Ilves and Airi Noppel \\ Faculty of Social Sciences, Institute of Education, University of Tartu, 50090 Tartu, Estonia; \\ helen.ilves@ut.ee (H.I.); airi.noppel@ut.ee (A.N.) \\ * Correspondence: katrin.saks@ut.ee
}

check for updates

Citation: Saks, K.; Ilves, H.; Noppel, A. The Impact of Procedural Knowledge on the Formation of Declarative Knowledge: How Accomplishing Activities Designed for Developing Learning Skills Impacts Teachers' Knowledge of Learning Skills. Educ. Sci. 2021, 11, 598. https://doi.org/10.3390/ educsci11100598

Academic Editor: Ching Sing Chai

Received: 16 August 2021

Accepted: 25 September 2021

Published: 30 September 2021

Publisher's Note: MDPI stays neutral with regard to jurisdictional claims in published maps and institutional affiliations.

Copyright: (c) 2021 by the authors. Licensee MDPI, Basel, Switzerland. This article is an open access article distributed under the terms and conditions of the Creative Commons Attribution (CC BY) license (https:/ / creativecommons.org/licenses/by/ $4.0 /)$.

\begin{abstract}
In addition to content knowledge, it is necessary to teach learning skills. Using relevant learning skills assures better learning outcomes and abilities for the whole life course. Due to a packed curriculum or teachers having insufficient skills, student learning skills are often neglected. The aim of this study is to find out whether it is possible to support the development of declarative knowledge in learning skills in teachers through procedural knowledge acquired via practical teaching activities. A quasi-experimental study using semi-structured pre- and post-intervention interviews and sixmonth intervention activities was conducted with 14 teachers. The procedural knowledge of the teachers was assessed based on their practical experience with the intervention activities. Their declarative knowledge was assessed based on pre- and post-intervention interview reflections. The findings revealed that procedural knowledge, being predominantly teacher centred, mostly appears through experience and reflections on the teaching practice that guides them. It also appeared that the intervention focusing on advancing procedural knowledge among teachers advanced their declarative knowledge in terms of metacognition, revealing new aspects of motivation and sensegiving for their learning. As follow-up research, we plan to continue studying conditional knowledge in teachers in order to identify situations where this is applied.
\end{abstract}

Keywords: declarative knowledge; procedural knowledge; learning skills

\section{Introduction}

The aim of education is forwarding factual content knowledge but also learning skillsamong which are cognitive and metacognitive skills. Good learning skills and academic self-regulation assure learning ability throughout life, supporting the development of a lifelong learner. However, far too often, not enough attention is paid to developing these skills. This lack of attention may be caused by a packed curriculum, a strong focus on teaching subject content [1], or teachers having insufficient ability and experience to teach learning skills [2]. Teacher knowledge and teaching practices have been researched in different contexts for decades, involving the role of prior knowledge and practical experience, as well as the social and institutional context in learning [3]. Teacher education programmes which are designed to prepare teachers to transfer content knowledge in the best didactic practices sometimes tend to neglect the importance of reflexive contextual experience [4,5].

The problem is teaching that predominantly focuses on subject content and tends to neglect the development and importance of learning skills [6]. Knowledge about the importance of learning skills and the possibility of developing them in classroom practice may reach teachers in different ways. Even though teacher education programmes handle this topic, without practical knowledge and personal experience, it may remain theoretical knowledge per se, and never be realised in real teaching-learning situations. Therefore, 
the current study explores the development of declarative knowledge through practical experience. This study aims to find out whether and to what extent it is possible to support the development of the declarative knowledge of learning skills in teachers through procedural knowledge acquired via practical teaching activities.

\subsection{Theoretical Framework}

In order to better understand and describe the concept of knowledge, different categories have been used. While Pol et al. [7] have identified declarative, procedural, and strategic knowledge. Mayer and Wittrock [8] separated declarative into factual and conceptual, and added metacognitive knowledge and beliefs. The last two are frequently combined into one-conditional knowledge (see, e.g., [9]), which lies in the individual's cognitive control and awareness of when, where, and why certain knowledge should be used. The current study is built on a framework with two main types of knowledgedeclarative and procedural. The former denoting the teachers' theoretical knowledge of learning skills and the importance of teaching and developing them, and the latter describing the practical knowledge acquired through the professional experience of teaching learning skills.

Declarative knowledge (also called descriptive, formal, or propositional knowledge or knowing-that) refers to facts or information stored in the memory and is, therefore, sometimes called declarative memory [10]. It is considered static in nature. Declarative knowledge describes things, events, and processes, and their relation to each other. According to Berge and Hezewijk [10] and Tulving [11], declarative knowledge is not conscious until it is retrieved by cues. The retrieval of declarative knowledge requires meaningful cues and directed attention and even then, may retrieve only a limited amount of potentially available information.

A significant part of teachers' declarative knowledge is gained during pre-service teacher education. Teacher candidates are equipped with a declarative knowledge base about effective teaching, which is necessary for later teaching practice and enables them to apply this to classroom situations [12,13]. General pedagogical knowledge is necessary in all teaching-learning situations. Declarative knowledge about effective teaching is an important condition for planning and implementing instruction [13] and is reflected in classroom practices as procedural knowledge.

Procedural knowledge (also called practical knowledge or knowing-how) involves an individual's skill and ability to accomplish an activity using certain strategies. Fenstermacher [14] defines it as the knowledge that the individual generates as a result of his experiences and his reflections on these experiences. Unlike declarative knowledge, procedural knowledge is not easily articulated since it is typically unconscious or tacit [15]. Star [16] distinguishes superficial- and deep-level procedural knowledge; the former is associated with rote learning, reproduction, and trial and error, while the latter is associated with comprehension, flexibility, and metacognitive knowledge, such as critical judgement [16]. The development of procedural knowledge is related to the development of declarative knowledge. Most learning occurs through a combination of declarative and procedural memory. Declarative knowledge is proceduralised through practice, which makes it possible to make connections between these two types of knowledge. Adaptive control of thought-rational (ACT-R) theory [17] describes the knowledge transition from a declarative to a procedural form. However, procedural and declarative knowledge may also be acquired separately, independently of each other. In the classroom, procedural knowledge is what is learned about the learning process-learning skills and strategies. This can be handled from the learner's perspective or teacher's perspective focusing on either, using appropriate learning strategies in certain learning situations or teaching students to better handle these learning situations. In order to be able to support learners in the acquisition of learning skills, it is crucial to have the basic (declarative) knowledge of the learning process and procedural knowledge of its techniques [18]. 
Based on the comparison of several studies, Meijer et al. [19] formulated the main characteristics that describe procedural knowledge in teachers. The first, personal procedural knowledge denotes an individual's knowledge, which is unique to them. This knowledge has a personal meaning for the individual based on his personal sense-making processes and experience [20]. Second, the contextual characteristic is defined as being 'in classroom situations'. This may also be unique but not as dependent on the individuality of the teacher, rather on the whole teaching-learning situation, which may occur in the classroom. The third characteristic, reflective [21,22], may be individual again depending on the length and richness of the teacher's work experience. The fourth, guiding teaching practice reflects the principles, but also beliefs and habits in teachers, that guide their teaching practice. The fifth characteristic which is attributed to procedural knowledge is being tacit [19] —all people have this knowledge but since it is not codified, it is not easily expressed [23] or noted. Unless clearly articulated, people may not even be aware of having this type of knowledge. Tacit knowledge is always personal, involving the emotions and values of the individual, closely connected to the teacher's individual beliefs and context [24]. Being rooted in the teacher's actions, experience and thoughts, it is not easily visible or explicable [25]. The last, sixth characteristic, describes the teacher's procedural knowledge related to the certain content taught in the classroom. Based on these characteristics, Meijer et al. formulated the definition of teachers' procedural knowledge as ' ... knowledge and beliefs that underlie his or her actions; this kind of knowledge is personal, related to context and content, often tacit, and based on (re-reflection on) experience' [19].

Even though studies on procedural knowledge in teachers tend to concentrate on some of these characteristics in studying this form of knowledge, the current research recognises all of these while analysing the teachers' self-reported experience of supporting the metacognitive learning skills of their learners.

\subsection{Developing Learning Skills in Learners}

Learning competence is the learner's ability to succeed in different learning situations and is one of the more essential underpinnings towards learning success, both in formal education and life-long learning. Learning competence is affected by a list of factors, most prominently by cognition, metacognition, and motivation, which also form the main categories in most frameworks of self-regulation (see, e.g., [26-28]). Cognitive and metacognitive learning skills are expressed in the meaningful use of learning strategies. Learning strategies are defined as systematic procedures or activities applied in the course of learning, and which support learners while working with texts and other study materials such as materials (see, e.g., [29]). Cognitive learning skills refer to cognitive, affective, and behavioural processes that the learner applies to achieve his learning goals and assesses the efficiency of his learning activities [30]. They are expressed in the ways the learner obtains, stores, and retrieves his knowledge and skills. Cognitive learning skills refer to procedural knowledge that enables the learner to perform cognitive behaviour. In the current context, it refers to an individual's thinking-related behaviour.

Metacognitive learning skills are usually related to metacognitive knowledge. Metacognitive knowledge is the conditional knowledge [9] of the relations between the learner, the learning task, and learning strategies [31]. It demonstrates the learner's knowledge and awareness of himself as a learner. Metacognitive learning skills refer to procedural knowledge regarding regulating and controlling learning behaviours [32,33]; hence, the practical output of metacognitive knowledge. The threefold division of metacognitive learning skills-planning the learning process and goal-setting, monitoring, and self-assessment-is predominantly the same in almost all theoretical frameworks (see, e.g., [34,35]).

Teaching learning skills is not easy, but it is possible. Various interventions have been created for this purpose such as teacher modelling [36] and thinking games [37], as well as specific learning-to-learn curricula [38]. In order to achieve success, it is important that the teacher and students are aware of the importance of developing learning skills and approach them consciously. According to the principles formulated by Bannert and 
Reimann [39], teaching learning strategies has to be integrated into subject courses and be a part of them. Teaching learning skills apart from content may not provide the expected results, as young or less experienced learners may not be able to transfer this skill from one domain to another. Therefore, it is important for the teachers of all subjects to pay attention to developing learning skills in their learners. Another important principle to follow is explaining the conditions and benefits of using learning strategies to the students. In order for the students to start using the strategies, they have to understand how these strategies enhance their learning process. Lastly, students have to be given enough time to practise new strategies so that they can be acquired and become automatic. Performing it only once is of no use [39].

Earlier research on procedural knowledge among teachers and their awareness of teaching learning skills is rather scarce. Most studies in the field have been conducted in the context of mathematics $[40,41]$ and less in language and reading comprehension (e.g., [19,42]) or ICT [43]. However, several studies investigating the role of teachers when teaching metacognitive skills (e.g., [44]) have demonstrated that successful teaching requires a complex understanding of the concept of metacognition and metacognitive learning strategies by the teacher [45-47].

The current study critically examines whether and to what extent it is possible to support developing the declarative knowledge of learning skills in teachers through procedural knowledge acquired through practical teaching activities. Proceeding from this aim, the following two research questions were posed:

1. How was the procedural knowledge of developing learning skills expressed in teachers after accomplishing the activities designed to support learning skills? In order to answer this research question, an intervention with 15 different activities was designed. After a two-hour training session and a six-month trial period, the teachers were interviewed to investigate their experience and personal perceptions of using these activities in practical classroom situations (knowing-how). The data were analysed deductively, using the theoretical framework involving six characteristics of procedural knowledge [19].

2. How did the declarative knowledge of learning skills in teachers evolve as a result of accomplishing the activities designed to support them? In order to answer this research question, the teachers' understanding and interpretation of learning skills were compared based on pre- and post-intervention interviews (knowing-that).

\section{Methods}

\subsection{Research Design}

In order to answer the research questions, a quasi-experimental study with pre- and post-assessment and intervention activities was conducted. In the first phase of the study, different lessons $(\mathrm{N}=11)$ were observed with the aim of identifying the activities of teachers as they supported the learning skills of their learners. After the observations, the teachers were interviewed to explore what meaning they gave to their activities, and how they understood the learning skills and the importance of developing them. The current study did not handle the results of the observations because these have been reported in a previous paper [6]. The focus of this study was on the semi-structured interview data collected before and after the intervention about the declarative and procedural knowledge of the teachers.

Proceeding from the results of the pre-assessment [6], the intervention activities were designed focusing predominantly on developing metacognitive learning skills in the learners. The activities were introduced to the teachers during a short two-hour training session, and the teachers were encouraged to perform them with their students. After a six-month intervention period, the teachers were interviewed again. The post-intervention interviews focused on teacher feedback on the activities but also their understanding of learning skills and their development. 


\subsection{Intervention}

A set of activities was created as an intervention for each different school levelpre-school, primary school, lower secondary, and secondary school. As the initial class observations conducted in the first phase of the study [6] had revealed that teachers offered sufficient support for cognitive learning skills in learners and insufficient support for metacognitive learning skills, the main focus of the intervention activities was on the latter and was enhanced with some cognitive strategies (e.g., activating previous knowledge, creating connections, reasoning, making conclusions, etc). The activities were grouped according to the taxonomy of metacognitive activities-planning, monitoring, and selfassessment [34,35]. While creating the intervention, we proceeded from the principles of Hannafin [48], Bannert and Reiman [39], and Tanner [49], who prioritise combining cognitive and metacognitive learning strategies with content knowledge, the use of an aware and meaningful approach to analysing one's learning process, and changing the metacognitive learning practices into automatic routines. The activities created for the intervention included a general description, instructional goals, instructions, reflective questions, and a sample of a worksheet if needed (see Appendix A for an example). In order to better prepare the teachers for accomplishing the activities, a two-hour face-toface training session was arranged at the schools and kindergartens of the teachers who belonged to the sample. The teachers were familiarised with the theories associated with learning skills and metacognition, and the main principles of teaching learning strategies. This was followed by practical activities, where the teachers could participate in the role of a learner, as well as a teacher. After the training, the intervention activities were shared with the participating teachers. The teachers were instructed to give feedback on each activity right after conducting these activities. To give feedback, the teachers were provided with a link to a Google Forms feedback document.

\subsection{Sample}

The sample for the study consisted of 14 teachers from different school levels (Table 1), all female. While pre-school and primary school teachers do not focus on teaching a single subject, the lower secondary and secondary school teachers were subject teachersEstonian (mother tongue), literature, English, mathematics, science, computer studies, economics, and media and communication. Their work experience ranged from 2 to 31 years $(M=14 ; S D=11)$. The teachers were approached through personal contacts the authors had from previous work experience in the education system.

Table 1. Demographic data on the sample.

\begin{tabular}{|c|c|c|c|}
\hline School Level & Pseudonym & $\begin{array}{c}\text { Years of } \\
\text { Experience }\end{array}$ & $\begin{array}{l}\text { Participation in } \\
\text { Pre-Assessment }\end{array}$ \\
\hline Pre-school & $\mathrm{T} 1$ & 13 & Yes \\
\hline Pre-school & $\mathrm{T} 2$ & 9 & Yes \\
\hline Pre-school & $\mathrm{T} 3$ & 25 & No \\
\hline Pre-school & $\mathrm{T} 4$ & 20 & Yes \\
\hline Primary school & T5 & 2 & Yes \\
\hline Primary school & T6 & 31 & Yes \\
\hline Lower secondary school & $\mathrm{T} 7$ & 27 & Yes \\
\hline Lower secondary school & $\mathrm{T} 8$ & 30 & No \\
\hline Lower secondary school & T9 & 3 & No \\
\hline Lower secondary school & $\mathrm{T} 10$ & 5 & Yes \\
\hline Lower secondary school & T11 & 4 & Yes \\
\hline Secondary school & $\mathrm{T} 12$ & 20 & Yes \\
\hline Secondary school & $\mathrm{T} 13$ & 2 & Yes \\
\hline Secondary school & $\mathrm{T} 14$ & 6 & Yes \\
\hline
\end{tabular}




\subsection{Data Collection and Analysis}

Data were collected in two phases-individual interviews to form a pre-assessment before the intervention, and again after the intervention. The aim of the pre-intervention interviews was to explore the teachers' declarative knowledge of learning skills, how they understood the concept of learning skills, and how important they considered teaching and developing them. The post-intervention interviews focused on exploring the teachers' perceptions of using the intervention activities; that is, their procedural knowledge of teaching learning skills and also their understandings (i.e., declarative knowledge) of the learning skills and the importance of teaching them.

The interviews with the teachers were recorded and transcribed in full. The data analysis used the techniques of thematic qualitative analysis and was supported with the web-based interactive software package QCAmap (www.qcamap.org, accessed on 5 June 2021). This software enables the coding of units according to pre-set categories in the case of deductive analysis, or according to the researcher's own categories in the case of inductive analysis. After uploading the data, the interviews were read repeatedly and coded according to the coding scheme. In order to ensure consistency in the interpretation of the data, the first two authors undertook parallel coding. Continuous reflective discussion between the researchers was used to reach a consensus and increase the quality of the study.

In order to answer the first research question, the teachers' practical experience of applying the activities designed to support student learning skills was analysed deductively based on the taxonomy of characteristics by Meijer et al. [19] .

In order to answer the second research question, the respondents' descriptions of learning skills and the importance of their development were analysed inductively. The teachers' declarative knowledge of learning skills before and after the intervention activities was compared. We aimed to find out whether their procedural knowledge enhanced via certain practical activities helped to clarify and elaborate their declarative knowledge of learning skills.

Although the sample consisted of teachers from different school levels, in the data analysis, they were not distinguished. Even though it could be assumed that the learners' learning skills are different at different school levels, and supporting learners of different ages assumes a different approach, the teachers' responses did not reveal any differences on the basis of age or school level. Therefore, all responses were analysed together, irrespective of the level at which the teachers were working.

\subsection{Ethical Considerations}

All ethical principles were followed when designing and conducting the research, and presenting the results. Prior to the start of the interviews, the participants were informed about the purpose of the study, data retention and further use, and the right to refrain from answering the questions at any time during the interview. The participants were asked for permission to record the interviews. In order to protect the privacy of the subjects, the names of the subjects were replaced with pseudonyms during the transcription process. The names and pseudonyms were stored separately, and only two researchers (the authors responsible for data analysis) had access to this information. The audio recordings and transcripts of the interviews were also available only to the researchers who performed the data analysis. The researchers were independent throughout the study, and there were no conflicts of interest.

\section{Results and Discussion}

The results of the analysis will now be presented and discussed according to the research questions. 


\subsection{Expressions of the Teachers' Procedural Knowledge of Developing Learning Skills after Accomplishing the Activities Designed to Support Them}

After the two-hour training session and the six-month experimenting, the teachers were interviewed to investigate their procedural knowledge of supporting learning skills in their learners. The interview data were analysed deductively grounded on the categories of the characteristics of procedural knowledge by Meijer et al. [19] and are presented accordingly. The results are supported and illustrated with extracts from the interviews. To situate the results, pseudonyms for the interviewed teachers are added after the quoted extracts below.

The first characteristic which emerged relied on the studies of Clandinin [50] and Elbaz [20] regarding the personal meaning that teachers attribute to their knowledge. This is the process of sense making based on their individual experience of instruction. The personal characteristic was revealed in seven subcategories and was most strongly represented by attitudes and beliefs (Learning skills are like tools, I cannot teach content when I haven't taught them how to learn it. T6), consistency (If you are consistent in what you're doing, then you can involve other teachers as well. T12), personal experience (I like to give them examples from my own experiences when I was younger and struggled with my studies. My students like to listen to these stories and they understand that facing difficulties when studying is okay. T8) but also professional development (As a novice teacher I am still testing different things and looking for the right way. If I do it properly and with proper tools, I will become more professional. T5). Not all reflections, however, were positive in their tone. Some teachers expressed their negative attitude towards spending (or wasting) time on teaching learning skills in the class and admitted being inconsistent when developing them (The curriculum is so packed, I just don't have time to play with them ... My colleagues have been wondering why I am doing such stupid things. For them this is waste of time. But I need better mapping where and how to use them. T9). Additionally, the personal experience of teaching learning skills may be disappointing for teachers when they lack the time and knowledge of how to do that.

The second contextual characteristic described by Meijer et al. [19] (p. 60) as being 'defined in, and adapted to, the classroom situation' appeared in six subcategories. The most frequent subcategory was a systematic approach which denoted the teacher's conscious and consistent activities in the teaching-learning situation (I re-thought my lesson structure again and considered where and how these activities could be used. It seemed to me that the new structure suited the students well. T14). In addition to re-structuring lessons, the teachers' systematic approach also expressed itself in creating the learning environment, which supports the development of learner autonomy, and giving more responsibility for the learning process to the students. The other subcategories that emerged were the teachers' readiness to experiment, trying out different methods and activities with different purposes (Depending on the topic I give them different tasks and expect them to apply different methods. I'm happy if they can recognise which methods work best in these situations but it is not always easy for them. T7), and the learners' comprehension (It was important to discuss with the students after each activity why we were doing these and how they were useful for them. If they don't understand the value of the activity, then it won't help them. T9).

The third characteristic, being reflective, tends to be most significant while describing teachers' procedural knowledge. A total of 136 utterances reflecting the teachers' practical experience were divided into 3 main categories (teacher related, learner related, parent related) and 24 subcategories. The most influential subcategories that emerged as teacher related were connected with their previous background knowledge (I used to be connected with the Step-by-Step (https: / /www.opensocietyfoundations.org/voices / first-steps-briefhistory-step-step-program, accessed on 21 June 2021) programme, therefore, employing similar principles was not new for me. T3), but also with class size (Those kinds of activities would be much more effective in a smaller class but if I have 26 or even more students ... it's very difficult to handle them. T10) and different educational needs (So many students 
in the class, so many different skills, levels and needs. T6; When you're working at school then you know that no method works equally well with all students. T7). The teachers also raised the necessity of investigating the students' previous knowledge, the importance of motivating students, and planning the activities ahead. The main obstacles, however, seemed to be lack of time, which is mostly caused by the curriculum being overly packed and there being too few lessons to cover all topics, as well as an excessive focus on grades rather than the acquisition of content and skills.

The main subcategories which stood out as learner related were students' cognitive skills, giving sense to learning, and motivation. While reflecting on the cognitive skills of their students, several teachers, mostly at the primary school level, admitted very low or even missing skills (Many of them cannot even read yet, then you cannot expect any higher-order thinking skills from them. T5). The intervention activities, however, seemed to have had a positive effect on their cognitive skills (They became much more independent in their thinking, they focused on themselves, their skills and strengths. T11; These practices made children much more courageous; they dare to express their opinion now. T8). Teachers recorded their students' fixed mindset (They are sure that if they don't understand something, then they won't, and nothing can change it. It's difficult to overcome this barrier. T9) and low concentration (It is difficult to keep their attention. If they can't focus, they don't understand why they need it. They just expect to get through the school day and that's all. T7). Several students could not understand why they were performing the reflection exercises. For young learners who are not used to metacognitively reflecting on their learning activities, it may be incomprehensible and seemingly useless. Here, the teacher is the key person who can bring this knowledge to the students-explaining the idea of these activities, and how the learners can benefit from them. The teachers who could create a motivating learning atmosphere detected higher engagement and deeper sense giving (They were seriously thinking why they were doing these tasks, and why they go to school at all. T10). Those students whose attention could not be kept said they could not accomplish the task, did not want to accomplish it, or it was stupid and boring (Smartphones and other digital devices have led them to a situation where they cannot accept that they are bored. T6).

The number of parent-related codes was low; however, from the teachers' perspective, this still deserved attention. The attitude of the general teachers towards the potential of parents when supporting student learning skills was mostly negative; teachers do not tend to believe that the parents had the skills to support their children's learning (Due to their own learning experience, the parents seem to believe that grades are most important and are sceptical about non-traditional teaching methods. T5). If the parents had the necessary knowledge and skills, they could be considered partners in the teaching-learning process.

The fourth category, guiding teaching practice, also revealed teacher-related and learner-related subcategories, and additionally-a collaboration with students. While the two former subcategories clearly distinguished the roles that the teacher or students take in the learning process, the latter was expressed in mutual partnership (I let each group choose their own topic and set their own goals, then I helped them to find suitable materials and guided them if they needed further guidance. T13). The main activities which appeared in the teacher-related teaching practice were explaining and guiding-I give them the assignment and then explain why it is wise to do it this way, and I hope it helps them understand it (T7). According to Bannert and Reiman [39], explaining the application conditions and the usefulness of acquiring the learning strategies is of crucial importance. Otherwise, students may feel their learning is disturbed and interrupted and, therefore, do not start using these strategies [51]. Sometimes teachers give examples of their own learning experience explaining how they are used to learning and what has helped them. Teachers also admit that very often they have to guide the students to use certain learning strategies step by step (I discuss different methods with my students. I encourage them to make mistakes and try again. I constantly have to affirm that making mistakes is a part of learning. T14). If the learners do not have previous experience of using 
learning strategies consciously, they need more guidance and explanations. The number of learner-related codes was not large; however, they are important because they express the teacher's readiness to consider the learners learning needs and expectations, and forward the responsibility for the learning process to the learners (When they set goals for their learning, they also need to assess how well they achieved these goals. It's not easy to make them analyse their learning outcomes. T14). As the teaching practice is still predominantly teacher centred, the students are rarely given the possibility to take responsibility for their learning and make informed choices for more efficient learning.

The fifth characteristic of procedural knowledge, being implicit, was expressed only in rare cases, mostly in subconscious activities, and recognised through in-depth reflection (It turned out that what I had been doing on my own initiative for a while, was right. Now I know how to label it ... T12). Teachers also admitted that learners' learning skills may be regularly supported subconsciously, but to make the required commitment of time for this and to do it overtly is not feasible for teachers. This is where teachers could acknowledge that developing and paying conscious attention to learning skills is the beginning of the process. Once these skills have been acquired, they become automatised and do not need special attention or time from teachers or learners.

The last and sixth characteristic, being content related, is partly connected with contextuality. However, while the main subcategories of contextuality were mostly about the learners' cognitive activities such as comprehension, content relatedness uncovered metacognitive activities-activating previous knowledge, planning and connecting, what emerged as teachers revised activating previous knowledge, and their constructivist learning approach [52] (We should know what they already know about the topic, what they want to know about it and then we start building new knowledge on it. T1). Planning was handled from different perspectives, by the teachers about themselves (If, at the beginning of a new topic, I inform the children about the goals and plans of the class, it is also easier for them to understand what is going to happen and what they should be ready for. T4) and by the teachers about the learners (I let them make their own plan for learning which should have helped them get answers to their questions and hence, achieve their goals. T11). Similarly, the connections were handled from the same two perspectives, that of the teachers (I need mapping to see the big picture and see how the topics are related to each other. Then it is easier for me to explain it also to the students. T5) and learners (I use bridging so that the students could connect the things we are learning with their knowledge from other classes. T12). Connecting skill is necessary on different levels-connecting content knowledge within a subject and between subjects and also connecting one's metacognitive experience so that it raises the students' awareness of themselves as learners.

This analysis based on the theoretical framework of Meijer et al. [19] enabled the categorisation of the teachers' procedural knowledge based on six characteristics. It is possible that a different analysis framework would have elicited a different set of results, but the current theoretical framework provided a rich set of data about experiences, guiding teaching practices, and personal characteristics.

If we observe the most dominant subcategories which reflect the teachers' procedural knowledge (Table 2), a strong bias towards teacher centredness appears. This means that teachers mostly reflect upon their practices through their own activities and perceptions, and the learners' perspective remains significantly less represented. Another distinction which appeared while comparing teachers' reflections was their positive or negative perception of their ability to develop learning skills in their learners. The teachers with a positive attitude had many relevant examples to bring from their teaching practice; they believed in their learners' ability to develop and enhance their learning skills, and they did not consider external obstacles or the lack of resources a problem. The teachers with negative attitudes, however, tended to display a fixed mindset [53], they did not believe their students were able to advance and improve their learning skills. These teachers also tended to minimise their role while supporting the development of their students and their 
learning skills. Next, we investigate whether the teachers' declarative knowledge changed as a result of these intervention activities and how.

Table 2. The most dominant subcategories of the teachers' procedural knowledge [19].

\begin{tabular}{|c|c|c|}
\hline Characteristic & Teacher's Perspective & Learner's Perspective \\
\hline Personal & $\begin{array}{l}\text { Attitudes and beliefs } \\
\text { Consistency } \\
\text { Personal experience } \\
\text { Professional development }\end{array}$ & \\
\hline Contextual & $\begin{array}{l}\text { Systematic approach } \\
\text { Experimenting }\end{array}$ & Comprehension \\
\hline Reflective & $\begin{array}{c}\text { Previous background } \\
\text { knowledge } \\
\text { Class size } \\
\text { Different educational needs }\end{array}$ & $\begin{array}{l}\text { Cognitive skills } \\
\text { Sense giving } \\
\text { Motivation }\end{array}$ \\
\hline Guiding teaching practice & $\begin{array}{c}\text { Collaboration with students } \\
\text { Explaining } \\
\text { Guiding }\end{array}$ & $\begin{array}{l}\text { Collaboration with students } \\
\text { Learners' interests } \\
\text { Learners' choices }\end{array}$ \\
\hline Tacit & Unconscious activities & \\
\hline Content related & $\begin{array}{l}\text { Previous knowledge } \\
\text { Planning } \\
\text { Connecting }\end{array}$ & $\begin{array}{l}\text { Planning } \\
\text { Connecting }\end{array}$ \\
\hline
\end{tabular}

3.2. The Change in Teachers' Declarative Knowledge of Learning Skills after Accomplishing the Activities Designed to Support Them

In order to understand the teachers' declarative knowledge of learning skills, two questions were asked: (1) How do you understand 'learning skills'? (2) Are learning skills important? Why (not)? The analysis of pre-intervention interviews revealed 54 meaningful utterances that expressed teachers' declarative knowledge of learning skills. These were coded using five different codes in the cognition category and eight codes in the metacognition category (see Table 3). Post-intervention interviews revealed 64 utterances, coded using 6 codes in the cognition category and 8 codes in the metacognition category. The following table distinguishes the codes according to their presence only in the pre- or post-intervention interviews, or in both.

Table 3. The occurrence of codes (indicating declarative knowledge) based on the interviews.

\begin{tabular}{|c|c|c|c|}
\hline & $\begin{array}{c}\text { Codes in } \\
\text { Pre-Intervention } \\
\text { Interviews }\end{array}$ & $\begin{array}{l}\text { Codes in Both Pre- and } \\
\text { Post-Intervention } \\
\text { Interviews }\end{array}$ & $\begin{array}{c}\text { Codes in Post-Intervention } \\
\text { Interviews }\end{array}$ \\
\hline 落 & $\begin{array}{l}\text { Finding solutions } \\
\text { Reasoning skills }\end{array}$ & $\begin{array}{c}\text { Comprehension } \\
\text { Cognitive strategies } \\
\text { Finding information, } \\
\text { materials }\end{array}$ & $\begin{array}{l}\text { Ability to work with } \\
\text { materials } \\
\text { Memory strategies } \\
\text { Effective acquisition }\end{array}$ \\
\hline 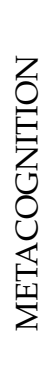 & $\begin{array}{c}\text { Focusing } \\
\text { Setting goals } \\
\text { Self-assessment } \\
\text { Tricks of work } \\
\text { Ability to make choices }\end{array}$ & $\begin{array}{c}\text { Independence } \\
\text { Learning together } \\
\text { Awareness of suitable } \\
\text { strategies, using suitable } \\
\text { strategies }\end{array}$ & $\begin{array}{c}\text { Control over one's own } \\
\text { learning } \\
\text { Building on one's own } \\
\text { previous experience } \\
\text { Making sense of one's own } \\
\text { learning } \\
\text { Finding and keeping } \\
\text { motivation } \\
\text { Readiness for learning, } \\
\text { being motivated }\end{array}$ \\
\hline
\end{tabular}


Considering our aim to detect the changes in teachers' declarative knowledge after accomplishing the intervention activities, we predominantly focused on the new codes that appeared in the post-intervention interviews but had not been apparent in the preintervention interviews.

In the teachers' expressions of their declarative knowledge of learning skills, two main divisions could be distinguished-cognitive skills and metacognitive skills. One of the new codes that emerged in the post-intervention interviews was the learners' ability to work with study materials. This involves the critical evaluation of the material, understanding its content and relevance, and relatedness with previously learned material. Learning skill is the learner's ability to work with materials so that it is understood, connected with the things learnt before and through this-acquired effectively (T7). During the pre-intervention interviews, the teachers' expression of their declarative knowledge of learning skills seemed limited to the ability to find suitable materials focusing predominantly on critical reading and assessment of the content and sources, the post-intervention interviews exposed a deeper understanding involving follow-up activities with the new study material.

Another emerging code in the post-intervention interviews was memory strategies, a code which is also related to the ability to work with materials but in a more limited scope. Memory strategies are cognitive learning strategies that, for example, in the domain of foreign language learning are mostly attributed to beginners [51,54]. The more skilful the learner is, the more memory strategies are replaced by higher-order cognitive skills [55]—connecting, comparing, contrasting, analysing, etc. Emphasising memory skills and techniques (focusing on memorising facts) was more characteristic of older generation teachers who received their teacher education in the era when behaviourist principles prevailed (Learning skills are learners' ability to memorise material, fix it, remember, and retrieve. T6). This finding, however, was not unexpected as the intervention activities designed for younger learners were enhanced with cognitive strategies, including memory strategies.

The third new code, effective acquisition, was mentioned by many interviewees $(n=11)$. However, the respondents seemed to understand effective acquisition differently. There were teachers $(n=8)$ for whom effective acquisition was limited to the classroom situation (How skilfully they approach the learning material and learn or acquire it, these are learning skills. T10), and teachers $(n=3)$ who evaluated the ability to apply the acquired knowledge outside the classroom and in subsequent life situations as effective acquisition (Learning skills are basically the transferrable skills that we could manage with learning or applying new knowledge. T9). Interestingly, reasoning and finding solutions, which were brought out in the pre-intervention interviews, were not mentioned as components of learning skills in the post-intervention interviews any longer, although these activities were practised within the intervention activities.

Unlike pre-intervention interviews, post-intervention interviews revealed the importance of motivation in addition to metacognitive activities (It is important for the child to find the will and energy that makes him want to learn and act. T2). The other elements that appeared in the interviews were control over one's own learning (This is the skill to control and direct one's learning. T9), building on previous experience (The skill to recall and use one's previous knowledge. T6), and making sense of one's own learning (It is important for him to understand why he is learning something and how he could benefit from it. T8).

In comparing the findings on the teachers' declarative and procedural knowledge, we could detect no consistency in regard to cognitive learning skills. For instance, teachers consider the learners' ability and skill in working with materials important, yet, while describing their practical experience, failed to refer to it. A similar omission was true of memory strategies. More consistency was observed in metacognitive activities-almost all categories that were detected in the declarative knowledge also appeared in the descriptions of their procedural knowledge. 


\section{Conclusions}

The current study aimed to find out whether and to what extent it is possible to support the development of teachers' declarative knowledge of learning skills through procedural knowledge acquired using practical teaching activities. In the scope of the first research question (How was the teachers' procedural knowledge of developing learning skills expressed after accomplishing the activities designed to support learning skills?), we found that teachers' procedural knowledge was predominantly teacher centred. Describing the practical learning activities in the classroom, the teachers' focus was mostly on themselves and less on the learners. It also appeared that their procedural knowledge was revealed mostly through experience and the reflections of the teaching practice that guides them. As practising such learning activities was the first experience for many of the teachers, we can expect them to become accustomed to applying these activities and transferring their attention from their activities to their students. Furthermore, the teachers' longer-term experience of developing student learning skills could be expressed in the individuality of the teachers' approach, their knowledge of learning skills, and the importance of developing them. These findings convey a message to teacher education programmes, which by increasingly linking theoretical teacher training with reflexive practical training should draw the attention of young teachers to techniques for developing student learning skills.

In light of the second research question (How did the teachers' declarative knowledge of learning skills evolve as a result of accomplishing the activities designed to support them?), it appeared that the intervention focusing on advancing teachers' procedural knowledge advanced their declarative knowledge in the scope of metacognition revealing new aspects of motivation and sense giving to one's learning. It became evident that the teachers' views of learning skills broadened considerably, and the learner's responsibility in the learning process was increasingly recognised, but the teachers also displayed a better perception of the learning process as a whole, where different knowledge, skills, and experiences are interconnected. From here on, it is important that teachers are able to put this knowledge into practice and to guide learners to make better use of their prior knowledge, both within and across disciplines, to help them create the big picture of what they are learning. At the same time, teachers' declarative knowledge of the importance of learning skills reflected their conviction in shaping an informed and autonomous learner. One of the main conclusions that we may draw from these findings confirms that developing learning skills should be a conscious activity for teachers, as well as for learners, then the learners can be more receptive to new ideas and strategies [39].

\section{Limitations and Implications for Further Research}

Although the research design was carefully planned and prepared, there were some limitations which are necessary to consider when interpreting the findings. The first limitation of the study is the small sample size that may make the findings less generalisable. However, the main conclusions about the change in the teachers' declarative knowledge depend very much on the intervention applied during the study. A different intervention and a different approach to the activities designed to develop the learners' learning skills may have elicited different results. Another limitation which could have affected the final conclusions is connected with the coding scheme based on the characteristics of Meijer et al. [19]. Sometimes, it was very difficult to distinguish whether an utterance expressed one or the other characteristic (e.g., contextual or content related, or experience or guiding teaching). Additionally, it seemed sometimes that tacit knowledge was expressed in the personal characteristic. In order to reduce the impact of this limitation, inter-coding was used.

While the current study sheds light on teachers' declarative and procedural knowledge of developing learning skills in learners, further research is necessary to study their conditional knowledge and find out in which situations this knowledge is applied. 
Author Contributions: Conceptualization, K.S., H.I. and A.N.; methodology, K.S., H.I. and A.N.; formal analysis, K.S.; investigation, K.S., H.I. and A.N.; resources, K.S., H.I. and A.N.; data curation, H.I. and A.N.; writing—original draft preparation, K.S.; writing—review and editing, K.S. and H.I.; supervision, K.S.; project administration, K.S.; funding acquisition, K.S. All authors have read and agreed to the published version of the manuscript.

Funding: This research was funded by the European Social Fund, project "Enhancement of Research and Development Capacity of Teacher Education Competence Centre Pedagogicum" (20142020.1.02.18-0645).

Institutional Review Board Statement: Ethical review and approval were waived for this study, as it involved only adults who all gave informed consent for their participation. No sensitive personal data were used in the study.

Informed Consent Statement: Informed consent was obtained from all subjects involved in the study.

Data Availability Statement: Not applicable.

Conflicts of Interest: The authors declare no conflict of interest.

\section{Appendix A}

Table A1. A sample worksheet of an intervention activity for pre-school.

\begin{tabular}{|c|c|c|}
\hline Name of Activity & \multicolumn{2}{|l|}{ Visualising Goals } \\
\hline School level & \multicolumn{2}{|l|}{ Pre-school } \\
\hline Aim of the activity & \multicolumn{2}{|c|}{$\begin{array}{l}\text { Visualising as a tool for planning and goal-setting is suitable for younger } \\
\text { learners. This makes future aspirations which may seem abstract more } \\
\text { concrete and achievable. In this activity, the learners are led to think } \\
\text { about a better 'me' and find ways to achieve this better 'me'. }\end{array}$} \\
\hline \multirow[t]{5}{*}{ Description } & \multicolumn{2}{|c|}{$\begin{array}{l}\text { In this task, the students are given a two-part table. On its left side, the } \\
\text { students depict themselves/their activities as they are. On the right side } \\
\text { of the table, they draw themselves / their activities as they want to see } \\
\text { them in the future. The topics that can be visualised and set goals for } \\
\text { could be, for example, the following: doing sports, healthy eating, } \\
\text { relations with friends, housework (e.g., helping parents), etc. } \\
\text { This activity could be accomplished according to one activity/goal, e.g., } \\
\text { to make a plan for the weekend, and on Monday, the children can reflect } \\
\text { on how it went. Additionally, this activity may be adapted to a longer } \\
\text { period, e.g., in summer, and in autumn they can reflect what they } \\
\text { accomplished and what they did not. } \\
\text { Sample worksheet (Healthy eating) }\end{array}$} \\
\hline & $\begin{array}{l}\text { How Am I Eating } \\
\text { Now }\end{array}$ & $\begin{array}{l}\text { How Would I like to } \\
\text { Eat in the Future }\end{array}$ \\
\hline & \multicolumn{2}{|l|}{ Breakfast } \\
\hline & \multicolumn{2}{|l|}{ Lunch } \\
\hline & \multicolumn{2}{|l|}{ Dinner } \\
\hline Digital component & \multicolumn{2}{|c|}{$\begin{array}{c}\text { The table may also be completed on a laptop or tablet using a } \\
\text { drawing program. }\end{array}$} \\
\hline
\end{tabular}

\section{References}

1. Čepić, R.; Pejić Papak, P. Challenges of Curriculum Planning and Achieving Learning Outcomes: A Case Study of Croatian Elementary School Teachers' Experiences. Rev. Rom. Pentru Educ. Multidimens. 2021, 13, 78-100. [CrossRef]

2. Baldan Babayigit, B.; Guven, M. Self-Regulated Learning Skills of Undergraduate Students and the Role of Higher Education in Promoting Self-Regulation. Eurasian J. Educ. Res. 2020, 89, 47-70. [CrossRef]

3. Freeman, D. The hidden side of the work: Teacher knowledge and learning to teach. Lang. Teach. 2002, 35, 1-13. [CrossRef]

4. Hammerness, K.; Klette, K. Indicators of Quality in Teacher Education: Looking at Features of Teacher Education from an International Perspective. In Promoting and Sustaining a Quality Teacher Workforce; Emerald Group Publishing Limited: Bingley, UK, 2015; pp. 239-277. [CrossRef] 
5. Grossman, P.; Hammerness, K.; McDonald, M. Redefining teaching, re-imagining teacher education. Teach. Teach. Theory Pract. 2009, 15, 273-289. [CrossRef]

6. Saks, K.; Noppel, A.; Ilves, H. Teachers' Awareness and Practical Activities when Facilitating Learners' Learning Skills. In Proceedings of the 11th ICEEPSY The International Conference on Education and Educational Psychology, Virtual Conference, 6-8 October 2020.

7. Pol, H.J.; Harskamp, E.G.; Suhre, C.J.M.; Goedhart, M.J. How indirect supportive digital help during and after solving physics problems can improve problem-solving abilities. Comput. Educ. 2009, 53, 34-50. [CrossRef]

8. Mayer, R.E.; Wittrock, M.C. Problem Solving Transfer. In Handbook of Educational Psychology, 2nd ed.; Alexander, P.A., Winne, P.H., Eds.; Lawrence Erlbaum: London, UK, 2006; pp. 47-62.

9. Turns, S.R.; Van Meter, P.N. Applying knowledge from educational psychology and cognitive science to a first course in thermodynamics. Paper Presented at the ASEE AnnualConference, Vancouver, BC, Canada, 26-29 June 2011. Available online: https: / / peer.asee.org/17500 (accessed on 4 August 2021).

10. Ten Berge, T.; Van Hezewijk, R. Procedural and Declarative Knowledge. An Evolutionary Perspective. Theory Psychol. 1999, 9 , 605-624. [CrossRef]

11. Tulving, E. How many memory systems are there? Am. Psychol. 1985, 40, 385-398. [CrossRef]

12. Darling-Hammond, L.; Bransford, J.D. Preparing Teachers for a Changing World: What Teachers Should Learn and Be Able to Do; Jossey-Bass: San Franscisco, CA, USA, 2005.

13. Stürmer, K.; Könings, K.D.; Seidel, T. Declarative knowledge and professional vision in teacher education: Effect of courses in teaching and learning. Br. J. Educ. Psychol. 2013, 83, 467-483. [CrossRef]

14. Fenstermacher, G.D. The knower and known: The nature of knowledge in research on teaching. Rev. Res. Teach. 1994, 20, 3-56. [CrossRef]

15. Stadler, M.A. On learning complex procedural knowledge. J. Exp. Psychol. Learn. Mem. Cogn. 1989, 15, 1061-1069. [CrossRef]

16. Star, J.R. Reconceptualizing Procedural Knowledge. J. Res. Math. Educ. 2005, 36, 404-411. [CrossRef]

17. Anderson, J.R. Rules of the Mind; Lawrence Erlbaum Associates Inc.: Hillside, NJ, USA, 1993.

18. Schiefelbein, E.; McGinn, N.F. The Process of Learning. In Learning to Educate; Sense Publishers: Rotterdam, The Netherlands, 2017; pp. 25-53. [CrossRef]

19. Meijer, P.C.; Verloop, N.; Beijaard, D. Exploring language teachers' practical knowledge about teaching reading comprehension. Teach. Teach. Educ. 1999, 15, 59-84. [CrossRef]

20. Elbaz, F. Research on teacher's knowledge: The evolution of a discourse. J. Curric. Stud. 1991, 23, 1-19. [CrossRef]

21. Verloop, N.; Van-Driel, J.; Meijer, P. Teacher knowledge and the knowledge base of teaching. Int. J. Educ. Res. 2001, 35, 441-461. [CrossRef]

22. Chaharbashloo, H.; Gholami, K.; Aliasgari, M.; Talebzadeh, H.; Mousapour, N. Analytical reflection on teachers' practical knowledge: A case study of exemplary teachers in an educational reform context. Teach. Teach. Educ. 2020, 87, 1-15. [CrossRef]

23. Chugh, R. Do Australian Universities Encourage Tacit Knowledge Transfer? In Proceedings of the 7th International Joint Conference on Knowledge Discovery, Knowledge Engineering and Knowledge Management, Lisbon, Portugal, 12-14 November 2015; pp. 128-135. [CrossRef]

24. Krátká, J. Tacit Knowledge in Stories of Expert Teachers. Procedia Soc. Behav. Sci. 2015, 171, 837-846. [CrossRef]

25. Wasonga, T.A.; Murphy, J.F. Learning from tacit knowledge: The impact of the internship. Int. J. Educ. Manag. 2006, 20, 153-163. [CrossRef]

26. Boekaerts, M. Self-regulated learning at the junction of cognition and motivation. Eur. Psychol. 1996, 2, 100-112. [CrossRef]

27. Cleary, T.; Zimmerman, B.J. A cyclical self-regulatory account of student engagement: Theoretical foundations and applications. In Handbook of Research on Student Engagement; Christenson, S.L., Reschley, W., Eds.; Springer Science: New York, NY, USA, 2012; pp. 237-257.

28. Zimmerman, B.J.; Moylan, A.R. Self-regulation: Where metacognition and motivation intersect. In Handbook of Metacognition in Education; Hacker, D.J., Dunlosky, J., Graesser, A.C., Eds.; Routledge: New York, NY, USA, 2009; pp. $299-315$.

29. Meneghetti, C.; De Beni, R.; Cornoldi, C. Strategic knowledge and consistency in students with good and poor study skills. Eur. J. Cogn. Psychol. 2007, 19, 628-649. [CrossRef]

30. Cantor, N.; Zirkel, S. Personality, cognition, and purposive behavior. In Handbook of Personality: Theory and Research; Pervin, L.A., Ed.; The Guilford Press: New York, NY, USA, 1990; pp. 135-164.

31. Flavell, J.H. Metacognition and cognitive monitoring: A new area of cognitivedevelopmental inquiry. Am. Psychol. 1979, 34, 906-911. [CrossRef]

32. Brown, A.L.; DeLoache, J.S. Skills, plans, and self-regulation. In Children's Thinking: What Develops? Siegel, R.S., Ed.; Erlbaum: Hillsdale, NJ, USA, 1978; pp. 3-35.

33. Veenman, M.J.; Kok, R.; Blöte, A.W. The relation between intellectual and metacognitive skills in early adolescence. Instr. Sci. 2005, 33, 193-211. [CrossRef]

34. Zimmerman, B.J. Becoming a self-regulated learner: Which are the key subprocesses. Contemp. Educ. Psychol. 1986, 11, 307-313. [CrossRef]

35. Pintrich, P. The role of goal orientation in self-regulated learning. In Handbook of Self-Regulation; Boekaerts, M., Pintrich, P., Zeidner, M., Eds.; Academic Press: San Diego, CA, USA, 2000; pp. 451-502. 
36. Hung, W. Enhancing Systems-Thinking Skills with Modelling. Br. J. Educ. Technol. 2008, 39, 1099-1120. [CrossRef]

37. Ouellet, M.-C.; Beauchamp, M.H.; Owen, A.M.; Doyon, J. Acquring a Cognitive Skill with a New Repeating Version of the Tower of London Task. Can. J. Exp. Psychol. 2004, 58, 272-288. [CrossRef]

38. Tuckmann, B.W.; Kennedy, G.J. Teaching learning strategies to increase success of first-term college students. J. Exp. Educ. 2011, 79, 478-504. [CrossRef]

39. Bannert, M.; Reimann, P. Supporting self-regulated hypermedia learning through prompts. Instr. Sci. 2012, 40, 193-211. [CrossRef]

40. Khashan, K.H. Conceptual and Procedural Knowledge of Rational Numbers for Riyadh Elementary School Teachers. J. Educ. Hum. Dev. 2014, 3, 181-197. [CrossRef]

41. Miller, S.P.; Hudson, P.J. Using Evidence-Based Practices to Build Mathematics Competence Related to Conceptual, Procedural, and Declarative Knowledge. Learn. Disabil. Res. Pract. 2007, 22, 47-57. [CrossRef]

42. Yazdanpanah, M.; Sahragard, R.A. Comparison of Expert and Novice Iranian EFL Teachers' Procedural Knowledge in Iranian Language Institutes and Universities. Iran. J. Appl. Lang. Stud. 2017, 9, 209-251.

43. Adegbenro, J.B.; Olugbara, O.O. Investigating Computer Application Technology Teachers' Procedural Knowledge and Pedagogical Practices in ICT- Enhanced Classrooms. Afr. Educ. Rev. 2019, 16, 1-18. [CrossRef]

44. Wilson, N.S.; Bai, H. The relationships and impact of teachers' metacognitive knowledge and pedagogical understandings of metacognition. Metacogn. Learn. 2010, 5, 269-288. [CrossRef]

45. Spruce, R.; Bol, L. Teacher beliefs, knowledge, and practice of self-regulated learning. Metacogn. Learn. 2015, 10, 245-277. [CrossRef]

46. Hargrove, R.A.; Nietfeld, J.L. The Impact of Metacognitive Instruction on Creative Problem Solving. J. Exp. Educ. 2015, 83, 291-318. [CrossRef]

47. Wall, K.; Hall, E. Teachers as metacognitive role models. Eur. J. Teach. Educ. 2016, 39, 403-418. [CrossRef]

48. Hannafin, M.; Land, S.; Oliver, K. Open learning environments: Foundation, methods, and models. In Instructional-Design Theories and Models: A New Paradigm of Instructional Theory; Reigeluth, C.M., Ed.; Lawrence Erlbaum: Mahwah, NJ, USA, 1999; Volume II, pp. 115-140.

49. Tanner, K.D. Promoting Student Metacognition. CBE-Life Sci. Educ. 2012, 11, 113-120. [CrossRef]

50. Clandinin, D.J. Classroom Practice: Teacher Images in Action; Falmer: London, UK, 1986.

51. Saks, K. Supporting Students' Self-Regulation and Language Learning Strategies in the Blended Course of Professional English. Ph.D. Thesis, University of Tartu, Tartu, Estonia, 2016.

52. Hein, G. Constructivist learning theory. In Developing Museum Exhibitions for Life-Long Learning; Durbin, G., Ed.; The Stationery Office: London, UK, 1996; pp. 30-34.

53. Dweck, C.S. Mindset: The New Psychology of Success; Ballantine Books: New York, NY, USA, 2006.

54. Oxford, R. Language Learning Strategies: What Every Teacher Should Know; Newbury House/Harper and Row: New York, NY, USA, 1990.

55. Saks, K.; Leijen, Ä. Cognitive and Metacognitive Strategies as Predictors of Language Learning Outcomes. Psihologija 2018, 51, 489-505. [CrossRef] 